\title{
Reflections of College English Majors' Cultural Perceptions on Learning English in Taiwan
}

\author{
Ching-Mei Cheng ${ }^{1}$ \\ ${ }^{1}$ Department of Applied English, HungKuang University, Taichung, Taiwan \\ Correspondence: Ching-Mei Cheng, HungKuang University, \#34 Chung-Chie Rd. Shalu, Taichung 433, Taiwan. \\ Tel: 886-928-206275. E-mail: 22jeanjean@gmail.com
}

Received: October 8, 2012 Accepted: October 16, 2012 Online Published: December 12, 2012

doi:10.5539/elt.v6n1p79 URL: http://dx.doi.org/10.5539/elt.v6n1p79

\begin{abstract}
This study was conducted with the participation of nine English as a Foreign Language (EFL) students and two EFL teachers of the Department of Applied English at an institute of technology in central Taiwan. Based on in-depth interviews with the students and teachers, the findings suggest that the participating students' perspectives of culture varied and that they were having difficulty interpreting deeper meanings associated with culture. American culture dominated their perceptions; culture learning was not considered important; culture was not yet emphasized in the classes; English is a lingua franca; culture understanding did not influence linguistic proficiency, and cultural self-awareness was not an issue. The participating students' ultimate educational goals were to earn an English-related certificate, and a cultural understanding of the language did not positively affect the proficiency. This study demonstrated that teaching and learning about culture are necessary and should be stressed in EFL education. The profound effect of cultural learning on language acquisition takes time to develop, and it requires learners' awareness to promote deeper understanding.
\end{abstract}

Keywords: culture and language, learners' beliefs, learning outcomes

\section{Introduction}

Given today's wide spreading globalization and the dominance of English as a lingua franca, communication in English is considered an indispensable competence in various fields. With globalization as the driving force consolidating the world on a new level, English as a Foreign Language (EFL) and English as a Second Language (ESL) educational programs are viewed as critically important as Graddol (2006) states that, "English now forms a key part of the educational strategy in most countries" (p. 70).

By bringing another language into the classrooms, language teachers are indeed exposing students to a completely new world that is socially, culturally, and linguistically different from the students' native cultures. However, the reality is that foreign language education has generally failed to provide the cultural dimension of languages to learners (Cheng, Yi \& Tsai, 2009; Kubota, Austin, \& Saito-Abbott, 2003; Paige et al., 1999; Sercu, 2005). The studies conducted in Taiwan (Cheng, Yi \& Tsai, 2009; Cheng, 2012) pointed out that cultural teaching is urgently needed to promote a deeper understanding of how a foreign/second language should be learned.

To emphasize the importance of cultural learning and teaching in the field of EFL/ESL, Sercu (2002) urged that future pedagogy in culture education should "move away from a teacher-led language-and-culture pedagogy to a student-centered autonomous learning approach" (p. 61). Gobel and Helmke (2010) strongly encouraged future research on students' cultural attitudes to provide insights into intercultural development in EFL education. Unlike studies focusing on teaching styles, Sercu (2002) emphasized the need to encourage learners to initiate cultural learning on their own. Although the issue of culture has been promoted in EFL education (Cheng, Yi, \& Tsai, 2009; Kramsch, 1998; Sercu, 2002 \& 2005), how EFL learners perceive culture should be assessed along with how such perceptions affect their English language learning.

The goal of the study is to shed light on the relationship between college EFL learners' perceptions about culture and their acquisition of the English language, such data could assist teachers in adopting and designing more sensitive curricula, catering to the real-world needs of learners and motivating students to initiate and internalize deeper levels of language and cultural learning. 


\section{Literature Review}

\subsection{Globalization and English}

English is widely recognized as a global language; more precisely, it is a lingua franca. With the influence of globalization, the number of EFL or ESL learners continues to increase, indicating status of English as a world language (Crystal, 2003). Sonntag (2003) addressed the phenomenon in the case of China stating that "there may now be more learners of English in China today than there are native speakers of the language" (p. xi). Kachru (1982) emphasized that "English has power..." (p. 355). Proficiency in English provides a comparative advantage and competitive edge, which is especially critical in this age of globalization (Cheng, 2011).

However, as English becomes more widespread, the concern of localization has been raised. Some authors insist that there should be a single standard form of English (e.g. Quirk, 1985) while others argue that several new varieties of Englishes have arisen (e.g. Kachru, 1985). Consequently, the "ownership" of English has been challenged and questioned for decades, as English has evolved across time, regions, and cultures (Saraceni, 2010; Widdowson, 1994). Despite this, the influence of globalization has helped contribute to the global status of English (Cheng, 2011; Nunan, 2003).

\subsection{Culture Learning in Foreign Language Education}

According to Sapir Whorf Hypothesis, the link between language and culture is obvious even though there has been criticism of their relationship (Mekheimer, 2011). The intertwined relationship between culture and language is settled, and the learning of a foreign or second language without culture is "inaccurate and incomplete" (Genc \& Bada, 2005, p. 73). Further, the need of teaching culture has been urged for decades as a substantial amount of research has shown (Byram, 1999; Canagarajah, 2006; Kramsch, 1995 \& 1998; Zaid, 2011). The impact of culture is positively linked to students' foreign language learning outcomes as Mekheimer (2011) emphasized that the cultural component of foreign language learning is beneficial in terms of language skills, raising cultural awareness, and changing attitudes toward target culture and societies.

\subsection{Learners' Beliefs and Learning Outcomes}

Beliefs are often defined as an individual's cognitions, judgments, conceptions, perspectives, views, and attitude, whether logical or emotional, that does not require formal justification. According to Sakui and Gaies (1999), beliefs are understandings that "arise from an individual's life history and educational experiences and which are the basis for judgments" (p. 474); additionally, beliefs are described as composing "a central construct in every discipline which deals with human behavior and learning" (p. 474). In other words, beliefs are considered important in constructing people's behavior. Beliefs, in terms of education, are the consequences of formal and informal learning experiences, and are crucial to one's learning outcomes. As a substantial amount of literature has revealed, student learning outcomes and achievement are closely related to their beliefs (Cotterall, 1999; Gremmo \& Riley, 1995; Mori, 1999; Suthar \& Tarmizi, 2010; Wenden, 1986). Beliefs, to a certain extent, can have direct impacts on performance and achievement and play a central role in learning experiences and processes. By considering learners' beliefs, teachers can better understand their students' learning experiences and, as a result, develop materials and curricula that better fit the real needs of their students.

To better understand students' performances and decision making, it is criticalto discover what constitutes their belief systems. More importantly, students'perceptions, beliefs, and awareness provide ways to examine teachers' classroom practices (Covill, 2011; Kolitch \& Dean, 1999; Qualters, 2001). Therefore, if students' beliefs can be revealed, instructional decision making can fit better with students' needs, and implementations can be launched adaptively and effectively.

\subsection{The Impacts from Teachers}

As Covill (2011) indicates, teachers are strong indicators of how education is conducted in classrooms, and student performances are reflective of classroom practices. Schoenfeld (1989) stresses that teaching style is crucial in developing students' beliefs, and beliefs can be changed. Regna and Dalla (1992) further suggest that students' beliefs can be improved when teachers are enthusiastic in their instruction. Having a direct impact on learning, teachers are a powerful force in determining how well our education systems work (Altan, 2006; Covill, 2011). By examining teachers' beliefs, we have a better chance of knowing what is actually taught in classrooms. Only by doing so can we devise implementations that are based on appropriate expectations for teachers and the practical needs of students.

\section{Research Questions}

Given the theoretical positions of the study, the aim was to provide answers to the following questions. 
1. What are college English-majors' perceptions of culture in Taiwan?

2. What perceptions, in terms of cultural education, do Taiwanese college English-major s' have about English language learning?

3. How do Taiwanese college English-majors' perceptions of cultural education affect their English language learning?

\section{Methodology}

\subsection{The Participants}

The research employed a qualitative case study approach to gain an in-depth and holistic understanding of learners' perspectives. In keeping with a tradition in qualitative research, I aimed for in-depth descriptions of the individual cases, while also attempting to identify some general trends and significant patterns among them.

Interviews are crucial to studies of EFL/ESL learners' perceptions (Benson \& Lor, 1999; Weden, 1986). The participant pool, containing both students and teachers, was selected from two cohorts, the sophomore and the junior, at the Department of Applied English at an institute of technology in central Taiwan, using networking sampling. All of the participating students were purposefully selected from the top $20 \%$ of each cohort, based on their accumulated grades. In general, students at this department are recruited from vocational or comprehensive senior high schools and are at around $50 \%$ percentile of the entire college entrance exam scores in Taiwan at the time of enrollment.

In this Department of Applied English, each grade level has only one cohort, which has not more than 50 students. All of the participating students were from sophomore and junior; the participating teachers had taught one or two courses to each cohort and had known the sophomore and junior students for at least two years. Tape-recorded and open-ended interviews with nine students and two teachers were conducted. Semi-structured interviews with open-ended questions were used because open-ended questions allowed the participants to fully reflect on their experiences (Seidman, 1990). Table 1 and 2 summarize the demographic characteristics of the participating students and teachers.

Table 1. The demographic information of the participating students

\begin{tabular}{|c|c|c|c|c|c|c|}
\hline & Gender & $\begin{array}{l}\text { Accumulated } \\
\text { grades }\end{array}$ & $\begin{array}{l}\text { Travel } \\
\text { abroad }\end{array}$ & $\begin{array}{l}\text { Study } \\
\text { abroad }\end{array}$ & $\begin{array}{l}\text { Experiences of } \\
\text { attending } \\
\text { cramming school }\end{array}$ & $\begin{array}{l}\text { English proficiency } \\
\text { Certificates/Grades }\end{array}$ \\
\hline $\begin{array}{l}\text { Student1, } \\
\text { Cohort } 1\end{array}$ & $\mathrm{M}$ & 89 & No & No & No & No \\
\hline $\begin{array}{l}\text { Student2, } \\
\text { Cohort } 1\end{array}$ & $\mathrm{~F}$ & 81 & Yes & No & No & No \\
\hline $\begin{array}{l}\text { Student3, } \\
\text { Cohort } 1\end{array}$ & $\mathrm{~F}$ & 90 & Yes & Yes & Yes & TOEIC/650 \\
\hline $\begin{array}{l}\text { Student4, } \\
\text { Cohort } 1\end{array}$ & $\mathrm{~F}$ & 82 & No & No & Yes & No \\
\hline $\begin{array}{l}\text { Student5, } \\
\text { Cohort } 1\end{array}$ & $\mathrm{~F}$ & 86 & No & No & No & No \\
\hline $\begin{array}{l}\text { Student6, } \\
\text { Cohort } 1\end{array}$ & $\mathrm{~F}$ & 85 & Yes & No & No & TOEIC/700 \\
\hline $\begin{array}{l}\text { Student } 7, \\
\text { Cohort } 2\end{array}$ & M & 92 & No & No & Yes & TOEIC/750 \\
\hline $\begin{array}{l}\text { Student 8, } \\
\text { Cohort } 2\end{array}$ & $\mathrm{~F}$ & 83 & No & No & Yes & TOEIC 705 \\
\hline $\begin{array}{l}\text { Student 9, } \\
\text { Cohort } 2\end{array}$ & $\mathrm{M}$ & 85 & Yes & Yes & Yes & TOEIC/805 \\
\hline
\end{tabular}

Table 2. The demographic information of the participating teachers

\begin{tabular}{|c|c|c|c|c|c|}
\hline & Gender & $\begin{array}{l}\text { Years of } \\
\text { Teaching }\end{array}$ & $\begin{array}{l}\text { Institutional } \\
\text { position }\end{array}$ & Courses taught to the class & $\begin{array}{l}\text { Study } \\
\text { abroad }\end{array}$ \\
\hline Teacher A & $\mathrm{F}$ & 10 & $\begin{array}{l}\text { Assistant } \\
\text { professor }\end{array}$ & $\begin{array}{l}\text { 1. English } \\
\text { Grammar(Required) } \\
\text { 2. English } \\
\text { Listening(Required) }\end{array}$ & $\begin{array}{l}\text { Yes/ } \\
\text { U.S.A / } 4 \\
\text { years }\end{array}$ \\
\hline Teacher B & $\mathrm{F}$ & 13 & $\begin{array}{l}\text { Assistant } \\
\text { professor }\end{array}$ & $\begin{array}{l}\text { 1. Reading } \\
\text { Discussion(Required) }\end{array}$ & $\begin{array}{l}\text { Yes } \\
\text { U.S.A / } 3 \\
\text { years }\end{array}$ \\
\hline
\end{tabular}




\subsection{Data Collection}

Data collection for this study occurred over 4 months and included fifteen scheduled interviews (60 to 90 minutes per interview) with the participating students, four scheduled interviews with the participating teachers, and an analysis of relevant document.

All interviews were conducted using interview protocols (see Appendices 1 and 2), and all interviews were conducted in Chinese, the native language of the participating teachers and students. Each interview was taped, transcribed in Chinese, translated into English and finally back-translated into Chinese by the researcher and her assistant. Translation scripts in Chinese and English from the researcher and her assistant were then cross-examined to maintain consistency and increase reliability. Grammatical errors in the translated transcripts were minimally corrected.

\subsection{Data Analysis}

Data analysis is a tool for synthesizing, examining, and organizing raw data in a systematic, consistent, and holistic manner. According to Miles and Huberman (1994), data analysis contains three interactive and iterative phrases, which are data reduction, data display, and conclusion drawing and verification. The three different phrases are interdependent and can be conducted simultaneously or at different point of time.

All of the transcripts were reviewed a number of times to be broken down into parts based on the research questions and the literature review. Then, the parts were reviewed a number of times again for the purpose of data reduction, which is a way to screen the relevant from the irrelevant. It is a process of extracting the essence from a pool of data. After the data are condensed and reduced, the process of coding proceeds. Coding helps researchers to identify the meanings within data in a systematic way. Strauss (1987) suggests that no further coding and recoding are needed when the categories are saturated and patterns have emerged. Next, key-words from each section were identified through multiple re-readings. Third, patterns of linkages and themes were identified among the key-words. Finally, a brief summary of the themes was developed to represent the participants' perspectives.

\section{Results from the Interviews and Documents}

\subsection{Results from the Interviews with Students}

Research question 1- What are college English-majors' perceptions of culture in Taiwan?

Themes from the interviews were: 1) culture involves characteristics, beliefs, values, and lifestyles; 2) culture is unique in each different country or region; 3) culture is abstract; 4) culture is shared; 5) culture involves different customs and traditions in different countries.

All of the participating students defined culture as the values, beliefs, and lifestyles shared by a particular group of people. Culture is, according to the subjects, the way people live and interact with others; culture is history; culture is about customs and traditions. The described meanings of culture varied, demonstrating the broad scope of the concept. Both objective and subjective cultures were included in participating students' understandings; however, it was difficult for them to interpret the deeper meanings associated with culture.

"To me, culture represents different characteristics from different countries. Just like us, each of us does have certain characteristics or personalities that make each of us different from each other. And, those differences represent the culture for that particular country... And, if nothing really goes differently for any of us, it shows that we, as the part of the world, do not have culture." [Student 1, Cohort 1]

"Culture is how a group of people live, how they behave, what they think, and how they organize their perspectives and beliefs. Moreover, culture includes customs and traditions because history is an important part of culture. Without history, culture cannot be created." [Student 2, Cohort 1]

"Culture is about how a group of people do things, and gradually culture evolves through time. So, culture is shared by that group of people. Only the members know how and why." [Student 4, Cohort 1]

"Culture, to me, is simply about traditions and customs. Take the Japanese for an example, white envelopes are accepted at the weddings while the Chinese consider the color white as bad luck for wedding. ...it is about how different group of people do things differently. Of course, the thoughts are different, too. We eat different food, speak different languages, listen to different kinds of music, and so forth." [Student 5, Cohort 1]

"Culture is hard to define. It is just like that Americans are different from us. And, we are different from Japanese...we eat different food. Americans go to churches on weekends, but we go to temples." [Student 7, Cohort 2] 
"Culture is quite difficult to explain because I have never thought of such question. But, I think it might be the things like holidays, food, festivals, and traditions. We have different festivals from Americans. For example, we don't consider Christmas as a national holiday in Taiwan. But, more and more students are celebrating Christmas in their own ways. They [the Taiwanese] go to parties and have Christmas dinner with their friends and family." [Student 9, Cohort 2]

Research question 2- What perceptions, in terms of cultural education, do Taiwanese college English-major s have about English language learning?

A few themes were found: 1) American culture still dominated students'

perceptions of English language learning in terms of cultural education; 2) cultural education is not considered important in English language learning; 3) cultural education was not yet emphasized in the classes; 4) English is a lingua franca; 5) English is synonymous with internationalization; 6) cultural understanding does not influence linguistic proficiency; 7) cultural self-awareness was not an issue in English language learning.

During the interviews, seven of the participating students clearly identified American culture as the culture in English language learning. The participants emphasized that American culture is perceived as the most relevant to the English language in Taiwan and American culture was the primary culture presented in the classes.

"I believe that American English is still the standard because of the political and economic influence from America. The movies, TV programs we watch are usually made by American companies. Most of the movies we watch are made in Hollywood ... usually, you get to meet more Americans than foreigners from other countries." [Student 1, Cohort 1]

"American culture is more emphasized because American English is widely used and accepted in Taiwan. When you speak in other accents, people would immediately catch the difference. I also find it hard to understand people in accents other than American English. " [Student 2, Cohort 1]

"I am more familiar with American culture because most of my teachers studied in America or are from America. To me, I have never thought of the question as what culture English really contains. English is just English. It is just a language that most people would use in international settings. ...our teachers rarely talk about the cultural issues because cultural understanding does not really influence your proficiency. So, if there is any, I guess it would be American culture." [Student 3, Cohort 1]

"At school, all of our foreign teachers are from America. Besides, most of our teachers studied in America, and they tended to share their study-abroad experiences from America. ...In Taiwan, we are mostly influenced by America because of the movies from Hollywood and media broadcasting. Even though it is true that there are many varieties in terms of English, I still consider American English to be the standard. Plus, the textbooks CD are usually recorded in American accent." [Student 6, Cohort 1]

"...American culture is easier to get. I think Taiwan is more influenced by American culture than any other cultures in the world. Take educational system for example, we [the Taiwanese educational system] follow American system...And, personally I am more in favor of American pronunciation. I have been learning American English since I started learning English.” [Student 7, Cohort 2]

"To me, I am very fascinated by American culture since I started learning English. I like to know things about what Americans do, what they think, and why they perceive things in certain ways. American culture is fun to learn, especially through the movies that I watch and songs that I listen to...I have never doubted the culture in English because I have considered American culture to be the main stream. "[Student 8, Cohort 2]

"I guess American culture is the culture in English learning because we [our educational system] follow American system... a funny example is that we usually assume the foreigners in Taiwan are from America. It seems that there are no other foreign countries around the world. I sometimes wonder why most of us have perceptions like this. Personally, I think I understand better and prefer American accent in terms of English learning. " [Student 9, Cohort 2]

Of the nine students, none considered cultural education to be crucial for English language acquisition. They expressed the opinion that linguistic proficiency does not relate to cultural knowledge and that English language learning is based on grammatical precision. Furthermore, the notion that English proficiency is a tool was repeatedly mentioned; the participants perceived the English language as a tool that can assist them in gaining knowledge in other fields. They also mentioned that culture could be approached as a topic separate from English language courses.

"To me, English is a very practical tool, which allows you to communicate with people from around the world. 
English is really an interesting language with which you find it easy to build the bridge between you and other foreigners. I think it is because English is an international language....English is just a tool and culture learning is such a minor issue because a tool is simply a tool. Culture has to do with geographical boundary, which does not apply to English because English is an international language. It does not have boundary." [Student 1, Cohort 1$]$

"There is no culture in English. We learn English to communicate with people from everywhere. For example, I chat with my Japanese net friend in English and Skype my Korean friend in English, too. We use English to talk about all the different cultural things, such as customs and practices. Culture makes no sense in English. English is a tool that allows us to communicate." [Student 2, Cohort 1]

"I have never thought about the culture in English because I have never taken any classes emphasizing the issue of culture. English is learned to communicate with people in international settings. You learn about others through English." [Student 3, Cohort 1]

"Culture has never become an issue in any of the classes that I have taken. To me, I think culture shouldn't be referred to any specific one, but to a broader inclusion of others. But, personally I think it is necessary to know how a language is used by native speakers. ...translation does not guarantee the complete switch of languages." [Student 4, Cohort 1]

"Language is used to communicate with others and does not have to do with culture. And, there is no culture in a language. ...we understand each other through the use of a language. A language is invented to deliver messages and meanings. A language is simply just a language, just a tool. With the tool, you try to make people understand your point of views. With the tool, you can make people understand your culture. So, it is not about the culture, but more about the language. I think culture and language are different things. ...culture can be learned in other subjects. In English classes, it is more about the language itself. "[Student 5, Cohort 1]

"English learning is more about practice. The more you practice, the better results (scores for English related certificates) you would get. You want to be fluent in a language; you need to dip yourself in all-English environment. In terms of culture, I think it would be fun if you are interested. But, for me, I would prefer to work on a practical side, which is to improve my TOEIC scores because it would directly show my proficiency in English. With an outstanding certificate, it will definitely help you in your further study or employment." [Student 9, Cohort 2]

All of the participating students admitted that culture had never been addressed in the classes they had taken. Language proficiency was emphasized through the practices of listening, speaking, reading, and writing; grammatical precision thus clearly outweighed the cultural understanding of a language. The relationship between language and culture had never been approached because it was not considered critical to them in terms of English language acquisition.

The fact that English is an international language was not denied by any of the participating students. They admitted that English is such an influential language that proficiency in it would certainly provide a competitive edge.

"To me, English is an international language, a very powerful tool. The magical thing about English is that you can communicate with people from around the world with English... for people who do not speak English fluently can come up with a few words of English. For example, a simply 'Hello' or 'hi' is English. "[Student 1, Cohort 1]

"English is truly a powerful language. People speak English, not French or German when they talk to people from different countries. "[Student 2, Cohort 1]

"From elementary school on, an English class is required. But we do not have to take other language classes, such as Japanese, Korean, German, or French. This is because English is the most important foreign language. We speak English to people from Europe, Japan, France, or other places." [Student 3, Cohort 1]

"I want to learn English because I know English is the only language that people commonly use from around the world." [Student 5, Cohort 1]

"English proficiency is important. If you can speak English well, you have a good tool to explore what you want to know because a lot of information on the Internet is in English. Plus, you usually get a better pay if you have an English proficiency certificate." [Student 6, Cohort 1]

"English proficiency is so important that the students nowadays cannot live without. Without the English skill, your salary will definitely be cut down, and it would be hard for you to find a good job." [Student 8, Cohort 2] 
"...I would prefer to work on a practical side, which is to improve my TOEIC scores because it would directly show my proficiency in English. With an outstanding certificate, it will definitely help you in your further study or employment." [Student 9, Cohort 2]

When discussing the issue of cultural self-awareness, all of the participating students displayed a sense of surprise. They held that cultural self-awareness is not an issue in English language learning. The participating students claimed that Taiwanese culture had defined their lives, and it shouldn't be necessary to discuss it during their English classes. However, the students did find it interesting to compare different cultures in classes.

Research question 3-- How do Taiwanese college English-majors' perceptions of cultural education affect their English language learning?

Common themes were: 1) the goal of learning English was to earn a certificate; 2) cultural education helps to increase the understanding of a foreign language; 3) cultural education was not recognized; and 4) the participating students' accumulated grades and English proficiency test results did not seem to reflect the importance of culture in English language learning.

Apparently, none of the participating students found cultural understanding to be crucial in terms of English language learning. During the interviews, eight of the students revealed goals of obtaining certificates in English proficiency and stated that grammatical precision would help them to obtain better grades. Thus, English language learning remained at grammatical practice.

"My ultimate goal is to earn at least 800 points in the TOEIC exam before I graduate. I am working toward the goal that I set for myself....culture is interesting, but it is a minor issue. With cultural understanding, it helps and motivates you to study English. But, it does not affect my proficiency. I enjoyed the topic when my teacher mentioned their experiences abroad, but I don't think it is so important to consider culture as an issue or to take a course." [Student 1, Cohort 1]

"I had gone to England for a study-abroad program last summer. Because of the one-month stay there in England, I think I would like to return there for my master's degree. Now, my goal here is to pass a certain level of the TOEFL or IELTS exam. Without that, I will not be able to attend graduate programs in England. Those exams are basically different from other English proficiency tests [TOEIC exam], and it takes more time and efforts to see a better result." [Student 5, Cohort 1]

"English proficiency is recognized by one's test results. That is, the certificates are usually what people would consider. Speaking, listening, reading, and writing are not necessarily related to culture when you think from the point of test. For example, speaking is usually not included in many English proficiency tests. One can speak English well while he/she might not be able to do well on the tests. But, you can do well on the tests when you have good understanding of the grammar. To master a language, I still think that practice is the key. The rules and structure of a language should be well understood if you want to master a language, especially a foreign language." [Student 6, Cohort 1]

"I have been working hard on my TOEIC exam because I know what it can do to my future employment and further study. I even successfully applied to a study-abroad program with my TOEIC 805 score. I believe that the score, to a certain degree, shows one's capability. And, if you are an English major's, you really need that certificate to prove that you outperform your peers in your area study...culture is interesting, and I like what my American teachers have shared with us about their cultures, their country, and their life. But, those issues are more like causal talks. I don't take them as the issues that we shall emphasize in the classes. "[Student 9, Cohort 2]

All of the participating students revealed that culture had never been addressed in the courses that they had taken even though most of them did find the topic of culture interesting when it was brought up in class. Because of a lack of cultural knowledge, the students did not display understanding of the connection between culture and language. Their English language learning still focused on grammatical precision because preparing for an English-related proficiency test was a priority.

Even so, some participating students considered culture an interesting topic that could help them gain an understanding of the use of English by native speakers. Additionally, they admitted that cultural understanding would, in turn, motivate them to study English further.

"In our speaking courses, our teacher would still tell us some cultural differences, which is especially common for the foreign teachers because they know their own cultures well. For example, they sometimes emphasized that taboo was critical. You need to know what not to say or not to do when you interact with people from different cultures. For this part, I sometimes find it interesting because I then realized that people are really 


\section{different." [Student 1, Cohort 1]}

"I love hearing about my teachers'study-abroad experiences because their experiences brought us closer to the places that we would like to visit in the future. Plus, their experiences help us know how we can improve our English because you should know how to use a language correctly." [Student 2, Cohort 1].

"Since I had done to England last summer, I really hope that some of our teachers could tell us more about the life there in England. Unfortunately, only one of our teachers had studied in England. Knowing more about the culture in England would definitely help me prepare for my future study in England." [Student 5, Cohort 1]

"Unlike other topics, cultural topics are more relaxing and fun to share. Sometimes I like to hear others'real-life experiences, which might be something that could happen to us in the future. Learning English is just like that. We need to learn a "real-life" English, not just English for testing." [Student 6, Cohort 1]

"I like to talk to my foreign teachers because they are fun to talk to. They think differently, and they like to share their cultures with us. I like to know the cultural differences, especially when those things are from their personal lives, not from the movies or the media. If I get the chance, I would like to visit them in their countries to see what it is like to live in their countries...but I think culture is not a topic that would be focused in the classes because the courses in the department emphasize on linguistic proficiency." [Student 7, Cohort 2]

In analyzing the data, a few themes emerged: 1) textbooks dominated classroom instruction; 2) English was taught as a subject; 3) discussion with students was rare; 4) culture was not a focus in classroom teaching; 5) students were passive learners; 6) students enjoyed culture-related topics. The students conveyed their belief that culture is not considered an essential part of English language learning even though some of them showed an interest in culture- related topics. The participating students reportedly learned English as a tool that could be used to explore the world around them, and American culture was decidedly the culture that best represented English as a foreign language. The students could not seem to elaborate on the deeper meaning of culture, perhaps because of a lack of knowledge regarding culture-related issues. English language study remained grammatically-focused for all of the student participants. Despite this, all of the students were motivated to polish their English-speaking ability as they all revealed high levels of interest in learning English since their study of the language had begun.

\subsection{Results from the Interviews with Teachers}

Interviews with the participating teachers (see Appendix 1) were based on the following issues: 1) how teachers adapt to EFL teaching and learning 2) the types of attributes learners make in the face of EFL learning.

Both teachers used only one textbook for each of the classes they taught, and the teachers indicated that supplementary materials were rarely used (see Appendix 3). Throughout the courses, textbooks typically provided guidance and structure for the instruction. Teacher A indicated the following:

"The textbook provides the guidelines for my classes. And, it is usually easier to follow the guidelines from textbooks. Plus, most of the textbooks nowadays provide additional materials when time is allowed to expand on the topics. Usually, I don't expand too much on the topics because of the limitation on time. Overall, textbooks do provide enough content for teaching and practice in my classes. Occasionally, I assign homework for my students if there is anything more that I want them to know."

The participating teachers indicated that English is taught as a subject with a focus on linguistic proficiency and precision. Teacher-centered lecturing was heavily used; and discussion with students rarely took place. Some examples are the following:

"In my grammar class, it is very important that they [the students] understand the basic structure of the language [English]. And, it is definitely necessary for them to acquire the basic structure of English before they move on to the next higher level. It's just like the rules of a game. Before you learn to play a game well, you need to know what rules to follow. I usually started my class with a review of the materials from the previous week, the new topics that I would like to cover, and finally a brief review of what I had gone through. I like things to be well-structured so students know what to expect." [Teacher A]

"The students in the class, to my understanding, are very quiet. They rarely have any questions or particular thoughts about the topics in the class. To make sure that they follow, I usually prepare a sheet of discussion questions for them to reflect on the reading materials that I assign. Therefore, they know what to expect in my class. I also give quite a lot of tests, compared with other teachers. The tests were given to force them to study." [Teacher B]

The participating teachers did not emphasize culture. Most of the course content was centered on grammatical 
precision and linguistic proficiency because students were required to pass a proficiency test before graduation. Both teachers noted these points in the following:

"The primary objective for them [the students] is to pass the TOEIC or GEPT exam. I would expect them to have at least 550 on the TOEIC (or the GEPT Intermediate level), even though I personally think 550 might not be good enough for applying for a good position in the job market. I think they need to acquire a certain level of proficiency when they finish the program here, and it is especially critical for them as an English-major graduate." [Teacher A]

"In my reading class, I would like my students to develop certain level of reading skills that they might need for their future study or even lifelong learning. So, I usually choose novels or stories that might interest them ... with the skills, they can move on to a higher level of proficiency. Of course, I would love to see them do pleasure reading for this class. But, there are structures and patterns that students need to understand." [Teacher B]

Even so, both teachers did recognize the necessity of acquiring cultural knowledge while learning English. The teachers considered United States culture as the target culture in EFL courses. Teacher B explained as follows,

"As an English-major student, you need to understand that culture is part of English learning. To students in Taiwan, we focus on American culture. Plus, most of the teachers received their degrees from America. So, it will be common that teachers talk mostly about their study-abroad experiences in America".

When discussing students' learning difficulties and potential problems experienced while studying English, both participating teachers mentioned that the students were generally not aggressive learners. The teachers both reported that most of the students in this particular class were passive learners lacking the motivation to pursue further study of the English language.

"The students in the class, to me, did not have the urge to study. To most of them, college education might be enough to find a job in the near future. They only care if they pass the classes or not. Nothing else really matters to them. Learning is meant to have the degree. ...It is hard to convince them [the students] that learning, especially self-learning, is for a lifetime." [Teacher A]

"In terms of proficiency, there is definitely lots of room for improvement for them. But, the problem is that they rarely have the urge to study. They rely heavily on the teachers to provide them exact instructions on what to do and how to do. Self-study rarely appears to them as their responsibility ... motivation and attitude do influence their learning outcomes ... in my class, I usually have three to four tests, which would help keep them on the track. Without the tests, it is fairly difficult to ask them to do any work." [Teacher B]

Even though cultural education was rarely incorporated by either teacher, each teacher observed that their students enjoyed hearing about study-abroad and travel experiences. The teachers' real-life experiences allowed the students to more closely examine cultural differences. The teachers believed that learning about others' experiences in a face-to-face context provided greater motivation for the students to learn. However, their teaching remained confined to grammatical precision because of the requirement that all students pass an English-proficiency test prior to graduation. Both of the participating teachers found fairly difficult to motivate their students in terms of self-learning.

\subsection{Document}

Each participating teacher used only one textbook throughout the course (see Appendices 3 and 4), and supplementary materials were rarely used. Both teachers were free to choose any desired textbooks for instruction. None of the textbooks contained any information about the local culture. Additionally, assignments were rarely given by the participating teachers. However, Teacher B did mention that she prepared discussion questions for the students to reflect on the reading content, and she reported giving quizzes on a regular basis to encourage studying.

The textbooks, Listen In 1 and Reading Explorer 2 are designed based on real-life topics, making English language learning more practical. Of the two textbooks used by both teachers, Reading Explorer 2 contains topics that could relate to the issues of culture, including culture in the Caribbean, the United States, Egypt, India, and the Middle East. The extensive topics in Reading Explorer 2 provides readers not only cultural knowledge but also with general information on various topics.

The book, Listen In 1, emphasizes individual learning strategies, providing questions for the learners to reflect on their own experiences. Some topics include cultural understanding of different ethnic groups. Generally speaking, the book includes a fair number of different voices from different cultures. 


\section{Discussion and Conclusions}

All of the participating students' accumulated grades were in the top $20 \%$ of the class, showing that to a certain degree they had better learning outcomes compared with the rest of their class. The interview results further indicate that English language acquisition might not be directly related to the cultural understanding of English because most participants repeatedly commented that cultural education did not affect their English proficiency. The students did not recognize that culture and language are firmly linked. More significantly, most of the students noted that cultural learning is not a necessity in terms of English language acquisition. The results do not support that cultural literacy is beneficial in foreign language learning outcomes as emphasized by many scholars (Genc \& Bada, 2005; Mekheimer, 2011).

Furthermore, the students' primary concern with English language learning remained grammatical precision. Earning an English-proficiency certificate represented, for many, the ultimate learning objective. Given that all of the participating students would be required to pass an English proficiency certificate prior to graduation, the students would not likely be convinced of the necessity of cultural education as a part of English language study. The findings reflect a highly negative attitude towards cultural learning as part of English language education. Overall, the findings seem to be indicative of learners' perceptions that culture does not play a part in their English language learning. The students' perceptions and beliefs also revealed that the English language learning journey was grade-driven and that linguistic proficiency would be determined by the outcomes of proficiency exams. One possible explanation for such a phenomenon may lie in the craze for English proficiency certificates in Taiwan and the beliefs in English's strength as a global language (Graddol, 2006). In conclusion, washback effect from testing was presented among the students as suggested by Alderson and Wall (1993).

These findings are not contradictory to some of the empirical studies discussed above regarding teachers' instructional practices. This study confirmed that culture-centered instruction is still rare (Cheng, Yi, \& Tsai, 2009; Cheng, 2012; Kubota, Austin, \& Saito-Abbott, 2003; Paige et al., 1999; Sercu, 2005). The participating teachers believed that culture-related topics could interest and motivate students' learning; however, the teachers' classroom practices were still greatly determined and confined by the content of proficiency tests. To fulfill the graduation requirement, the participating teachers seemed to direct their attention to the English proficiency tests. The participating teachers' instruction was in line with students' perceptions of culture, thus also directly influencing student beliefs. These findings are in agreement with the results of previous studies showing that students' perceptions reflect what their teachers do in the classrooms (Covill, 2011; Schoenfeld, 1989). More importantly, the participating teachers' classroom instruction was greatly influenced by English proficiency tests, which is emphasized by Alderson and Wall (1993) that the testing would greatly influence teachers' classroom instruction and students' learning.

As globalization increases worldwide, students in Taiwan have greater opportunities to interact with people around the world using of English. Therefore, teachers, especially EFL teachers, have become important agents, helping students to become more internationalized in the global village and to cultivate awareness of the differences among cultures. Even so, the fact remains that it is often difficult to convince EFL teachers that the learning of a foreign or second language without culture is "inaccurate and incomplete" (Genc \& Bada, 2005, p. 73). Raising awareness of cross-cultural understanding may be one of the most difficult tasks to approach as Hanvey (1976) emphasizes. However, teachers' intercultural experiences can contribute to students' cultural learning, and teachers' real-life intercultural experiences are closely related to their students' cultural learning outcomes (Gobel \& Helmke, 2010). EFL teachers, however, might not have enough intercultural experiences and cultural knowledge to share with their learners; similarly, and cultural experts are not necessarily proficient in foreign language. Only through cooperation among professionals can the ultimate objectives of foreign language education be realized.

Educational reform involves much more than material and curricula innovation; in addition, it requires changes in beliefs potentially leading to changes in actions (Tong and Cheng 2006). To promote more effective autonomous language learning in the age of globalization, it is suggested that learners be infused with the notion that culture and language are firmly linked and that language is culturally embedded (Kramsch, 1995 \& 1998). The profound effect of cultural understanding of a language takes time to develop, and it requires learners' awareness to promote a deeper understanding because the cultural dimension of a language is difficult to convey and measure as emphasized by Hanvey (1976) and Paige et al. (1999).

This study has demonstrated that cultural education is necessary and should be stressed in foreign language education. It follows that cultural instruction should be strengthened, and culture-related courses are needed. Future research should, therefore, investigate how EFL learners' beliefs can be changed with the adjustment of 
curricula and teaching contexts because learners' beliefs are, indeed, changeable especially when teachers are enthusiastic in their instruction (Regna \& Dalla, 1992).

\section{Acknowledgements}

The author would like to extend special thanks to participants who unselfishly shared their views. Without their involvement and participation, the study could not have been accomplished. Special thanks are also given to the reviewers for their expert suggestions.

\section{References}

Alderson, J. C., \& Wall, D. (1993). Does washback exist? Applied Linguistics, 14(2), 115-129. http://dx.doi.org/10.1093/applin/14.2.115

Altan, Mustapha. (2006). Beliefs about language learning of foreign language-major university students. Australian Journal of Teacher Education, 31(2), 45-52.

Benson, P., \& Lor, W. (1999). Conceptions of language and language learning. System, 27(4), 459-472. http://dx.doi.org/10.1016/S0346-251X(99)00045-7

Borg, M. (2001). Teachers' beliefs. ELT Journal, 55(2), 186-88. http://dx.doi.org/10.1093/elt/55.2.186

Byram, M., \& Risager, K. (1999). Language teachers, politics and cultures. Clevelon: multilingual Matters.

Canagarajah, S. (2006). Changing communicative needs, Revised assessment objectives: Testing English as an international language. Language Assessment Quarterly, 3(3), 229-242. http://dx.doi.org/10.1207/s15434311laq0303_1

Cheng, C. M., Yi, Lee-Yin, \& Tsai, C. (2009). A Case Study of Two EFL Teachers' Understanding of Culture. Studies in Humanities and Social Sciences, 10, 31-50.

Cheng, C. M. (2011). EFL Teachers' Perceptions of Globalization on English Language Instruction in the Realm of Elementary Level in Taiwan. Studies in Humanities and Social Sciences, 14, 33-58.

Cheng, C. M. (2012). The influence of college EFL teachers' understandings of intercultural competence on their pedagogical practices in Taiwan. English Teaching: Practice and Critique, 11(1), 164-182. New Zealand: Waikato University.

Cotterall, Sara. (1999). Key variables in language learning: what do learners believe about them? System, 27, 493-513.

Covill, A. E. (2011). College students' perceptions of the traditional lecture method. College Student Journal, 45, 92-101.

Crystal, D. (2003). English as a global language. Cambridge: Cambridge University Press.

Genc, B., \& Bada, E. (2005). Culture in language learning and teaching. The Reading Matrix, 5(1), 73-84.

Gobel, Kerstin, \& Helmke, Andreas. (2010). Intercultural learning in English as foreign language instruction: The importance of teachers' intercultural experience and the usefulness of precise instructional directives. Teaching and Teacher Education, 26, 1571-1582. http://dx.doi.org/10.1016/j.tate.2010.05.008

Graddol, D. (2006). English next: Why global English may mean the end of "English as a foreign language". London: British Council.

Gremmo, M. J., \& Riley, P. (1995). Autonomy, self-direction and self access in language teaching and learning: The history of an idea. System, 23(2), 151-164. http://dx.doi.org/10.1016/0346-251X(95)00002-2

Hanvey, G. (1976). An attainable global perspective. New York: Center for global Perspectives.

Kachru, B. B. (Ed.) (1982). The other tongue. English across cultures. Urbana: University of Illinois Press.

Kachru, B. B. (1985). Standards, codification and sociolinguistic realism: The English language in the outer circle. In R. Quirk, \& H. Widdowson (Eds.), English in the world: Teaching and learning the language and literatures (pp. 11-30). Cambridge: Cambridge University Press.

Kolitch, E., \& Dean, A. V. (1999). Student ratings of instruction in the USA: Hidden assumptions and missing conceptions about 'good' teaching. Studies in Higher Education, 24(1), 27-42.

Kramsch, C. (1995). The cultural component of language teaching. Language, Culture and Curriculum, 8(12), 83-92. http://dx.doi.org/10.1080/07908319509525192

Kramsch, C. (1998). Language and Culture. New York: Oxford university Press. 
Kubota, R., Austin, T., \& Saito-Abbott, Y. (2003). Diversity and inclusion of sociopolitical issues in foreign language classrooms: An exploratory survey. Foreign Language Annals, 36(1), 12-24.

McDonough, S. (1995). Strategy and Skill in Learning a Foreign Language. London: Edward Arnold.

Mekheimer, M. A. (2011). Impact of the target culture on foreign language learning: A case study. Cross-cultural Communication, 7(1), 43-52.

Mori, Yoshiko. (1999). Epistemological beliefs and language learning beliefs: What do language learners believe about their learning? Language Learning, 49(3), 377-415.

Miles, M. B., \& Huberman, A. M. (1994). Qualitative data analysis: An expanded sourcebook (2 ${ }^{\text {nd }}$ ed). Thousand Oaks, CA: Sage.

Nunan, D. (2003). The impact of English as a global language on educational policies and practices in the Asia-Pacific region. TESOL Quarterly, 37(4), 589-613. http://dx.doi.org/10.2307/3588214

Paige, R. M., Jorstad, H., Siaya, L., Klein, F., \& Colby, J. (1999). Culture learning in language education: A review of the research literature. In R. M. Paige, D. L. Lange, \& Y. A. Yershova (Eds.), Culture as the core: Integrating culture into the language curriculum (pp. 47-115). Minneapolis: University of Minnesota, Center for Advanced Research in Language Acquisition.

Regna, S., \& Dalla, L. (1992). Affect: A critical component of mathematical learning in early childhood. In R. J. Jensen (Ed.), Research ideas for the classroom: Early childhood (pp. 22-42). New York: McMillan.

Qualters, D. M. (2001). Do students want to be active? Journal of Scholarship of Learning and Teaching, 2, 51-60.

Quirk, R. (1985). The English language in a global context. In R. Quirk, \& H. G. Widdowson (Eds.), English in the world: Teaching and Learning the language and literatures (pp. 1-6). Cambridge: Cambridge University Press.

Riley, P. (1996). BATs and BALLs: Beliefs about talk and beliefs about Language Learning. Proceedings of the International conference AUTONOMY 2000: The Development of Learning independence in Language Learning, Bangkok, November, pp. 151-168.

Sakui, K., \& Gaies, S. J. (1999). Investigating Japanese learners' beliefs about language learning. System, 27 , 473-492. http://dx.doi.org/10.1016/S0346-251X(99)00046-9

Saceni, M. (2010). The relocation of English: Shifting paradigms in a global era. New York: PALGRAVE MACMILLAN.

Schoenfeld, A. H. (1989). Explorations of students' mathematical beliefs and behavior. Journal for Research in Mathematics Education, 20(4), 335-338. http://dx.doi.org/10.2307/749440

Seidman, I. E. (1991). Interviewing as qualitative research: A guide for researchers in education and social sciences. New York: Teachers College Press.

Sercu, L. (2002). Autonomous learning and the acquisition of intercultural communicative competence: Some implications for course development. Language, Culture and Curriculum, 15(1), 61-74.

Sercu, L. (2005). Teaching foreign languages in an intercultural world. In M. Byram, \& A. Phipps (Ed.), Foreign language teachers and intercultural competence (pp. 1-18). Buffalo: Multilingual Matters, Ltd.

Sonntag, S. K. (2003). The local politics of global English: Case studies in linguistic globalization. Maryland: The Rowman \& Littlefield Publishing Group, Inc.

Strauss, A. L. (1987). Qualitative analysis for social scientist. Cambridge: Cambridge University Press. http://dx.doi.org/10.1017/CBO9780511557842

Suthar, Velo., \& Tarmizi, R. Ahmad. (2010). Effects of students' beliefs on mathematics and achievement of university students: Regression Analysis Approach. Journal of social sciences, 6(2), 146-152.

Tong, C. W., \& M.-Y. Cheng. (2006). The Learning process of teaching beliefs: A case study. School reform and cooperation. Three Places across Two Shores Seminar, Hong Kong, Hong Kong Chinese University.

Wenden, A. (1986). What do second-language learners know about their language learning? A second look at retrospective accounts. Applied Linguistics, 7(2), 186-205.

Widdowson, H. G. (1994). The ownership of English. TESOL Quarterly, 28(2), 377-389. http://dx.doi.org/10.2307/3587438 
Zaid, M. (2011). Caught between Scylla and Charybdis: Teaching English in a Plethora of Dialects and Cultures.

Paper presented at Rhizomes VI, The University of Queensland, Brisbane, Australia.

\section{Appendix 1. Interview protocols for teachers}

1. What are the core objectives in classroom teaching?

2. What are the factors that can influence students' foreign language learning?

3. What obstacles do learners encounter in foreign language learning?

4. What do teachers think of the need to associate cultural understanding with students' foreign language learning?

\section{Appendix 2. Interview protocols for students}

1. What is culture?

2. What is culture in terms of learning English?

3. What are the factors that influence the outcomes of learning English?

4. How do the beliefs based in culture reflect on learners' English language learning?

5. What are learners' goals in the journey of learning English?

6. What obstacles do learners encounter in learning English?

\section{Appendix 3. The textbooks used by the participating teachers}

Table 3. The textbooks used by the participating teachers

\begin{tabular}{llllll}
\hline \multicolumn{2}{l}{ Name of the course } & Textbook & Author & Publisher & \\
\hline English & Listening- & Listen In 1 & David Nunan & Heinle & Cenage \\
Freshmen & & & Ben Adams & Learning & \\
English & Grammar- & Understanding and Using & Betty & Pearson & Education \\
Freshmen & & English Grammar & Schrampfer & Taiwan & \\
$\begin{array}{l}\text { Reading \& Discussion- } \\
\text { Freshmen }\end{array}$ & Reading Explorer 2 & Nancy Douglas & Heinle & Cengage \\
& & & Learning & \\
\hline
\end{tabular}

\section{Appendix 4. Summary of the textbook contents}

Table 4. Summary of the textbook contents

\begin{tabular}{|c|c|}
\hline Textbook & Summary of the Contents \\
\hline Listen In 1 & $\begin{array}{l}\text { 1. The topics in Listen In } 1 \text { are based on real-life situations, such } \\
\text { as following directions, listening to telephone messages, } \\
\text { entertainment, news, weather broadcast and understanding } \\
\text { announcements. } \\
\text { 2. Some topics include cultural understanding of different ethnic } \\
\text { groups. For example, it states that, "In Japan, it's unusual for } \\
\text { someone's parents to meet the person he or she is dating until they } \\
\text { decide to get married." (p. 71) } \\
\text { 3. The book emphasizes individual learning strategies, providing } \\
\text { questions for the learners to reflect on their own experiences. } \\
\text { 4. Generally speaking, the book includes a fair number of } \\
\text { different voices from different cultures. }\end{array}$ \\
\hline $\begin{array}{l}\text { Understanding and Using } \\
\text { English Grammar }\end{array}$ & $\begin{array}{l}\text { 1. The book covers a wide variety of usages of English. } \\
\text { 2. The book emphasizes concepts of English grammar and } \\
\text { includes diagrams or pictures to explain the topics. }\end{array}$ \\
\hline Reading Explorer 2 & $\begin{array}{l}\text { 1. Each unit of Reading Explorer } 2 \text { covers a wide variety of } \\
\text { real-world topics, including culture, art, science, social science, } \\
\text { environmental issues and medical fields. } \\
2 \text {. The content of Reading Explorer } 2 \text { include topics from around } \\
\text { the world, including the Caribbean, Egypt, Italy, the United States, } \\
\text { India, and the Middle East. }\end{array}$ \\
\hline
\end{tabular}

